\author{
Marquette University \\ e-Publications@Marquette
}

Civil and Environmental Engineering Faculty

Civil, Construction, and Environmental

Research and Publications

Engineering, Department of

2007

\title{
Efficacy of Removal of CCL Viruses under Enhanced Coagulation Conditions
}

Morteza Abbaszadegan

Arizona State University at the Tempe Campus

Brooke Mayer

Marquette University, Brooke.Mayer@marquette.edu

Hodon Ryu

Arizona State University at the Tempe Campus

Nena Nwachuku

Arizona State University at the Tempe Campus

Follow this and additional works at: https://epublications.marquette.edu/civengin_fac

Part of the Civil and Environmental Engineering Commons

\section{Recommended Citation}

Abbaszadegan, Morteza; Mayer, Brooke; Ryu, Hodon; and Nwachuku, Nena, "Efficacy of Removal of CCL Viruses under Enhanced Coagulation Conditions" (2007). Civil and Environmental Engineering Faculty Research and Publications. 31.

https://epublications.marquette.edu/civengin_fac/31 


\title{
Efficacy of Removal of CCL Viruses under Enhanced Coagulation Conditions
}

\author{
Morteza Abbaszadegan \\ Arizona State University, \\ Tempe, $A Z$ \\ Brooke K. Mayer \\ Arizona State University, \\ Tempe, $A Z$ \\ Hodon Ryu \\ Arizona State University, \\ Tempe, $A Z$ \\ Nena Nwachuku \\ United States Environmental Protection Agency, \\ Washington, DC
}

\section{Abstract}

The focus of coagulation as a water treatment process is shifting to accommodate recent regulatory additions that strive to balance the risks

Environmental Science \& Technology, Vol 41, No. 3 (2007): pg. 971-977. DOI. This article is @ American Chemical Society and permission has been granted for this version to appear in e-Publications@Marquette. American Chemical Society does not grant permission for this article to be further copied/distributed or hosted elsewhere without the express permission from American Chemical Society. 
between microbial and chemical contamination of drinking water. In this work, enhanced coagulation using increased ferric chloride dose and/or $\mathrm{pH}$ adjustment was evaluated for removal efficacy of viruses on the United States Environmental Protection Agency (USEPA) Contaminant Candidate List (CCL), their surrogates, and dissolved organic carbon (DOC). Jar tests demonstrated that optimal DOC removal was achieved using $40 \mathrm{mg} / \mathrm{L} \mathrm{FeCl}_{3}$ at a $\mathrm{pH}$ between 5 and 6 . Under these conditions, bench-scale testing resulted in a maximum removal of $2.58 \mathrm{log}$ units of adenovirus type 4, $2.50 \mathrm{log}$ units of feline calicivirus, $2.32 \log$ units of MS2, $1.75 \log$ units of PRD1, $1.52 \log$ units of phi-X174, $2.49 \log$ units of $\mathrm{fr}$, and $56 \%$ of DOC. The trend in virus removals (MS2 and fr > PRD1 and phi-X174) was consistent between bench- and pilotscale testing; however, pilot-plant removals exceeded bench-scale removals. Feline calicivirus was more efficiently removed than the bacteriophages, thereby suggesting potential for the bacteriophages as suitable surrogates, with MS2 and fr being more representative and PRD1 and phi-X174 (which were removed to a lesser extent) more conservative. The bacteriophages do not appear to be appropriate surrogates for adenovirus.

\section{Introduction}

In an effort to ensure the safety of the nation's drinking water, the United States Environmental Protection Agency (USEPA) continually develops and re-evaluates regulations targeting drinking water contaminants. Individually or in tandem, recently promulgated regulations such as the Enhanced Surface Water Treatment Rule (ESWTR) and the Disinfectants and Disinfection Byproduct (D/DBP) Rule might have important implications for the water treatment industry. The ESWTR and D/DBP Rule attempt to simultaneously balance the risks posed by microbial and chemical contaminants, particularly disinfection byproducts (DBPs). The removal of DBP precursors such as dissolved organic carbon (DOC) prior to disinfection is an effective means of limiting DBP forma tion. Enhanced coagulation was identified by the D/DBP Rule as the best available technology to remove DOC. ${ }^{1}$ Traditional coagulation processes target turbidity removal, whereas enhanced coagulation targets the removal of turbidity and natural organic matter (NOM) using increased coagulant dose and/or $\mathrm{pH}$ adjustment. ${ }^{2}$ The Stage 1 DBP Rule requires many systems using surface water or groundwater directly under the influence of surface water to implement enhanced coagulation. ${ }^{3}$ Enhanced coagulation might become an increasingly important treatment process as water utilities adapt their systems to comply with the D/DBP Rule. 
Although a great deal of attention has focused on the removal of DBP precursors from drinking water using enhanced coagulation $(1,2$, $4,5)$, limited information is available regarding the efficiency of enhanced coagulation for the removal of emerging pathogens. ${ }^{6}$ Conventional coagulation, flocculation, and sedimentation processes have demonstrated efficiency in the removal of a variety of microorganisms, including viruses, bacteria, and protozoa. ${ }^{7-9}$ There is a need for similar studies to determine how the optimization of enhanced coagulation for the reduction of NOM affects the removal of emerging pathogens such as those on the Contaminant Candidate List $(\mathrm{CCL})$. The $\mathrm{CCL}$ is a list of unregulated contaminants warranting priority research because they are believed to occur in public water systems and might be associated with adverse health effects. The CCL is revised every 5 years in an effort to reflect current priorities. The second CCL, which was published in February 2005, includes 9 microorganisms and 42 chemical contaminants. ${ }^{10}$

The overall objective of this study was to evaluate the removal of adenovirus and calicivirus (CCL viruses) and potential surrogates under enhanced coagulation conditions, as defined by DOC removal. Adenovirus type 4 and feline calicivirus, which are commonly used laboratory surrogates for enteric adenoviruses type 40 and 41 and human caliciviruses such as norovirus, were used in this study. Feline calicivirus (FCV) is not actually a CCL virus. However, it is the accepted laboratory model for studies of the removal and inactivation of human caliciviruses, for which an in vitro cell culture technique is not currently available. ${ }^{11,12}$ Thus, FCV was used to represent the physical removal of the CCL caliciviruses throughout this study. Future advances in in vitro techniques might allow for the direct study of human calicivirus removal and inactivation, which would be of great interest.

The results of this study will aid in building a database of the efficiencies of treatments of enteric viruses and their surrogates and in evaluating CCL viruses in terms of future regulatory determination. In this study, bacteriophages representing a range of physical characteristics, as listed in Table 1, were selected as potential CCL virus surrogates. Microorganisms with removal profiles similar to those of the CCL viruses are potential surrogates for the physical removal of the CCL viruses. Surrogates would be valuable because in vitro cell 
culture methods, which are used in the standard assay technique for animal viruses, are labor- and time-intensive and require specialized equipment and knowledge to perform. Thus, it was important to study bacteriophages in an attempt to identify appropriate surrogate microorganisms for the CCL viruses.

Table 1. Characteristics of CCL Viruses and Potential Surrogate Bacteriophages

\begin{tabular}{|c|c|c|c|c|}
\hline bacteriophage & bacterial host & size $(\mathrm{nm})$ & $\begin{array}{l}\text { isoelectric } \\
\text { point }\end{array}$ & genetic structure \\
\hline $\begin{array}{l}\text { MS2 (ATCC } \\
15597-B 1)\end{array}$ & $\begin{array}{l}\text { Escherichia coli } \\
\text { (ATCC 15597) }\end{array}$ & $24^{13}-27^{14}$ & $3.5^{8}-3.9^{13}$ & $\begin{array}{l}\text { single-stranded } \\
\text { RNA }\end{array}$ \\
\hline $\begin{array}{l}\text { PRD1 (ATCC } \\
\text { BAA-769-B1) }\end{array}$ & $\begin{array}{l}\text { Salmonella } \\
\text { typhimurium LT2 } \\
\text { (ATCC 19585) }\end{array}$ & $62^{14}-65^{15}$ & $3.0^{14}-4.2^{8}$ & $\begin{array}{l}\text { double-stranded } \\
\text { DNA }\end{array}$ \\
\hline $\begin{array}{l}\text { phi-X174 } \\
(13706-B 1)\end{array}$ & $\begin{array}{l}\text { Escherichia coli } \\
\text { (ATCC 13706) }\end{array}$ & $23^{14}-27^{13}$ & $6.6^{13}$ & $\begin{array}{l}\text { single-stranded } \\
\text { DNA }\end{array}$ \\
\hline $\begin{array}{l}\text { fr (ATCC 15767- } \\
\text { B1) }\end{array}$ & $\begin{array}{l}\text { Escherichia coli } \\
\text { (ATCC 19853) }\end{array}$ & $23^{16}$ & $8.9^{8}-9.0^{8}$ & $\begin{array}{l}\text { single-stranded } \\
\text { RNA }\end{array}$ \\
\hline CCL virus & cell line & size $(\mathrm{nm})$ & $\begin{array}{l}\text { isoelectric } \\
\text { point }\end{array}$ & genetic structure \\
\hline adenovirus & $\begin{array}{l}\text { PLC/PRF/5 (ATCC CRL- } \\
8024)\end{array}$ & $70^{17}-100^{18}$ & $--^{a}$ & $\begin{array}{l}\text { double-stranded } \\
\text { DNA }\end{array}$ \\
\hline feline calicivirus & CRFK (ATCC CCL-94) & $27^{19}-40^{19}$ & $-{ }^{a}$ & $\begin{array}{l}\text { single-stranded } \\
\text { RNA }\end{array}$ \\
\hline
\end{tabular}

${ }^{a}$ Determination of the isoelectric point of pathogenic viruses is very difficult, and few have been reported. The isoelectric points of adenovirus type 4 and feline calicivirus are currently undetermined.

\section{Materials and Methods}

\section{Source Water and Coagulants.}

Untreated water from the Chandler Water Treatment Plant (CWTP) in Chandler, AZ, was used as source water throughout this investigation. Influent water quality varies throughout the year based on a fluctuating blend of surface and groundwater. Water turbidity ranged from 3 to $20 \mathrm{NTU}, \mathrm{pH}$ from 8 to 8.5, alkalinity from 125 to 200 $\mathrm{mg} / \mathrm{L}$ as $\mathrm{CaCO}_{3}$, and DOC from 3 to $6 \mathrm{mg} / \mathrm{L}$. Variations in water quality parameters have been reported to significantly impact the performance of coagulation, sedimentation, and filtration. ${ }^{17,20}$ 
Alum and ferric chloride are the most commonly used coagulants in water treatment applications. ${ }^{17}$ Ferric chloride is more efficient than alum for NOM removal; ${ }^{17,21}$ however, there is no apparent consensus regarding coagulant selection for microbial removal. Alum was used in a related study, ${ }^{8}$ whereas ferric chloride (ferric chloride hexahydrate lumps, Sigma Chemical Co., St. Louis, MO) was used in this investigation. A cationic polymer, poly(dial Iyldimethylammonium chloride) (polyDADMAC; Clarifloc 350, Polydyne, Inc., Riceboro, GA), was used in conjunction with ferric chloride to improve floc settleability.

\section{Jar Testing.}

To simultaneously optimize ferric chloride dose and $\mathrm{pH}$ with respect to DOC removal, a series of bench-scale jar tests were performed. All jar-test experiments were performed using a six-jar PB700 Phipps \& Bird (Richmond, VA) jar-test apparatus. In addition to DOC removal, the removals of four bacteriophages (MS2, PRD1, phiX174, and $\mathrm{fr}$ ), adenovirus type 4, and feline calicivirus were measured under enhanced coagulation conditions. Initial tests demonstrated that DOC concentrations were distorted by the addition of nutrient media from the stock cultures of microorganisms. Thus, separate jar tests were conducted under identical enhanced coagulation conditions for the bacteriophages, CCL viruses, and DOC. Accordingly, one jar-test experiment was conducted to develop the removal profile for the bacteriophages, which were assayed in triplicate. Two jar-test experiments were conducted using the CCL viruses because time limitations prevented duplicate assays of a single experimental sample. The two CCL tests are referred to hereafter as the "first and second CCL virus experiments". For each of these three experiments, a separate jar-test experiment was performed to analyze DOC removal.

A 10-L sample of untreated water was collected from the CWTP for use in each jar-test experiment. The sample was transported and stored under darkened conditions at $4^{\circ} \mathrm{C}$. Jar tests were conducted within $48 \mathrm{~h}$ of sample collection. Prior to experimentation, the sample was allowed to return to room temperature $\left(21^{\circ} \mathrm{C}\right)$. The water was then seeded with a known number of microorganisms [final concentration of $1 \times 10^{6}$ plaque forming units (PFU) per milliliter of 
each bacteriophage or $1 \times 10^{6} 50 \%$ tissue culture infective dose ( TCID $_{50}$ ) per milliliter of each virus]. The seeded sample was thoroughly mixed for 15 min before being distributed in 1.5-L portions to each of the jars. The seeded water served as the control with respect to initial virus concentrations.

Immediately following microbial seeding, ferric chloride, cationic polymer, and $1 \mathrm{~N} \mathrm{HCl}$ were added to each jar. Ferric chloride doses are heavily dependent on water quality and are therefore widely variable. ${ }^{20}$ Enhanced coagulation doses range from 5 to $150 \mathrm{mg} / \mathrm{L} \mathrm{FeCl}_{3}{ }^{7}$ but are commonly in the range of $20-60 \mathrm{mg} / \mathrm{L} \mathrm{FeCl}_{3} .{ }^{5}$ Coagulant doses ranging from 0 to $120 \mathrm{mg} / \mathrm{L} \mathrm{FeCl}_{3}$ were tested in increments of 20 $\mathrm{mg} / \mathrm{L}$ in this study. Polymer was added at a constant dose of $0.4 \mathrm{mg} / \mathrm{L}$. Variations in polymer dose have not demonstrated a significant effect on DOC removal during enhanced coagulation; therefore, polymer dose was held constant. ${ }^{1}$ The optimal $\mathrm{pH}$ for coagulation of NOM with ferric chloride is approximately $4-5 ; 2,4$ however, for practical reasons, enhanced coagulation is generally carried out in a $\mathrm{pH}$ range of $5-7 .^{1}$ Target $\mathrm{pH}$ values ranging from 5.5 to 7.5 were tested using increments of roughly 0.5 as part of this investigation.

The jar-testing protocol used throughout this study was based on the protocol described by Volk et al. ${ }^{5}$ Immediately following chemical addition, rapid mixing was initiated at $100 \mathrm{rpm}$ for $1 \mathrm{~min}$. Mixing was slowed for the flocculation stage, which consisted of two 10 -min mixing periods at 40 and $20 \mathrm{rpm}$. Finally, the paddles were extracted, and the contents of the jars were allowed to settle for 30 min. Samples were collected from the center of each jar, approximately 2 in. below the surface. The samples were immediately assayed for bacteriophages, CCL viruses, or DOC; $\mathrm{pH}$; turbidity; and ultraviolet absorbance at a wavelength of $254 \mathrm{~nm}\left(\mathrm{UV}_{254}\right) . \mathrm{UV}_{254}$ was used to calculate specific UV absorbance [SUVA $=\mathrm{UV}_{254} / \mathrm{DOC}, \mathrm{L}$ (mg $\left.\mathrm{m})^{-1}\right]$, which is sometimes used as a surrogate measurement of DBP precursors. ${ }^{14}$ 


\section{Pilot-Plant Facility.}

After the coagulant dose and $\mathrm{pH}$ had been optimized using the jar-test apparatus, pilot-plant experiments were performed at the CWTP's pilot-plant facility using the potential surrogate bacteriophages (animal viruses were not permitted at the water treatment facility). The pilot-plant treatment train includes coagulation, flocculation, sedimentation, and filtration. A schematic is provided by Gerba et al. ${ }^{8}$ Full-scale plant parameters such as hydraulic residence time (HRT), chemical dosing, mixing, and surface loading rates were mimicked by the small-scale pilot plant, as shown in Table 1 in the Supporting Information. Based on full-scale facility flows, a high flow rate of 0.5 gpm $(1.9 \mathrm{~L} / \mathrm{min})$ and a low flow rate of $0.25 \mathrm{gpm}(1.0 \mathrm{~L} / \mathrm{min})$ were selected. The plant was operated for three HRTs prior to sampling such that steady-state conditions were achieved ( 6 and $12 \mathrm{~h}$ for the high and low flow rates, respectively).

The addition of bacteriophages, ferric chloride, polymer, and $\mathrm{HCl}$ was regulated using adjustable peristaltic pumps. Seeded water (final concentration of $1 \times 10^{6} \mathrm{PFU} / \mathrm{mL}$ of each bacteriophage) was mixed by an inline static mixer before entering a series of three coagulation/flocculation chambers separated by diffusion walls, each equipped with a propeller-type mixer. The mixers were staged to emulate the full-scale plant tapered flocculation sequence using progressively lower mixing intensities (35 rpm in the first tank, followed by 25 and $15 \mathrm{rpm}$ in the subsequent tanks). The water was then directed through the sedimentation basin before entering the dual media filters. The filters consisted of 3-in.-diameter acrylic columns containing $1.5 \mathrm{ft}$ of gravel support structure, topped with $1 \mathrm{ft}$ of sand, followed by $2 \mathrm{ft}$ of granular activated carbon (GAC). Water samples were collected at three loca tions: influent, settled, and filtered. Physicochemical parameters were analyzed onsite. The samples were transported to the laboratory under darkened conditions at $4{ }^{\circ} \mathrm{C}$ and were immediately assayed for bacteriophages.

\section{Bacteriophage Propagation and Assays.}

The bacterioph ages and bacterial hosts listed in Table 1 were obtained from the American Type Culture Collection (ATCC, Rockville,

Environmental Science \& Technology, Vol 41, No. 3 (2007): pg. 971-977. DOI. This article is @ American Chemical Society and permission has been granted for this version to appear in e-Publications@Marquette. American Chemical Society does not grant permission for this article to be further copied/distributed or hosted elsewhere without the express permission from American Chemical Society. 
MD). Bacteriophage stocks were propagated using the double agar layer (DAL) method. ${ }^{22}$ Approximately $10^{7} \mathrm{PFU}$ of bacteriophage, $1 \mathrm{~mL}$ of host bacteria, and $5 \mathrm{~mL}$ of $0.7 \%$ molten tryptic soy agar (TSA; Difco, Detroit, MI) were combined and poured onto $1.5 \%$ TSA plates. The plates were incubated at $37^{\circ} \mathrm{C}$ overnight. Bacteriophage stocks were collected the following day by adding $10 \mathrm{~mL}$ of $1 \mathrm{X}$ phosphate buffer saline (PBS) to the surface of the plate and allowing it to incubate at room temperature for $1 \mathrm{~h}$. The supernatant was collected and centrifuged at $4^{\circ} \mathrm{C}$ at $8000 \mathrm{~g}$ for $15 \mathrm{~min}$. The pellet was discarded, and the supernatant containing the bacterioph ages was stored at $4^{\circ} \mathrm{C}$. Typically, stock concentrations were on the order of $10^{10}$ $\mathrm{PFU} / \mathrm{mL}$. New stocks were propagated once the titer dropped below $10^{8} \mathrm{PFU} / \mathrm{mL}$.

Immediately following jar-test and pilot-plant experi ments, the water samples were serially diluted (10-fold) in 1X PBS (sufficient for up to 5-log removal) and were promptly assayed in triplicate for bacteriophages using the DAL method. ${ }^{22}$ The plates were incubated at $37^{\circ} \mathrm{C}$ overnight, and plaques were counted after $12 \mathrm{~h}$. Positive and negative controls were included in each set of assays for each bacteriophage.

\section{Virus Propagation and Assays.}

Adenovirus type 4 (Ad4, ATCC VR-4) was obtained from the ATCC and was cultured using primary liver cancer cells (PLC/PRF/5, ATCC CRL-8024) in 1X Eagle's minimum essential medium (MEM) containing $10 \%$ fetal bovine serum (FBS). Feline calicivirus (FCV, ATCC VR-652) was obtained from the ATCC and was cultured using Crandall feline kidney cells (CRFK, ATCC CCL-94) in 1X MEM containing 10\% equine serum. The $1 X$ MEM was supplemented with $1.5 \mathrm{~g} / \mathrm{L}$ sodium bicarbonate, $15 \mathrm{mM}$ Hepes, $2 \mathrm{mM}$ l-glutamine, $0.1 \mathrm{mM}$ non-essential amino acids, $1 \mathrm{mM}$ sodium pyruvate, $100 \mu \mathrm{g} / \mathrm{mL}$ antimycotic, and 100 $\mu \mathrm{g} / \mathrm{mL}$ kanamycin sulfate.

Virus stocks were propagated by inoculating the cells with a stock suspension of approximately $1 \times 10^{6} \mathrm{TCID}_{50} / \mathrm{mL}$. The flasks were incubated at $37{ }^{\circ} \mathrm{C}$ until at least $90 \%$ of the cells were infected. Cells were then subjected to freeze/thaw cycles: one for Ad4 and three for 
FCV-infected cells. ${ }^{23}$ The supernatant was centrifuged at $4{ }^{\circ} \mathrm{C}$ at $8000 \mathrm{~g}$ for $15 \mathrm{~min}$ to remove cellular debris. The virus suspension was purified and concentrated using poly(ethylene glycol) (PEG) precipitation, as described by Thurston-Enriquez et al. ${ }^{23}$ Briefly, the suspension was augmented with $9 \%$ PEG (MW 8000) and $1 \mathrm{M} \mathrm{NaCl}$ and was allowed to stir overnight at $4^{\circ} \mathrm{C}$. It was then centrifuged at $4^{\circ} \mathrm{C}$ at $8000 \mathrm{~g}$ for 90 min. The supernatant was discarded, and the pellet was resuspended in $10 \%$ of its original volume of $1 \mathrm{X}$ PBS. To remove lipids and facilitate the monodispersion of viruses, a Vertrel XF (Micro Care Marketing Services, New Britain, CT) extraction was performed by centrifuging a suspension of equal parts Vertrel and virus at $4^{\circ} \mathrm{C}$ at $8000 \mathrm{~g}$ for 90 $\min .^{23}$ The supernatant containing the purified viruses was stored at $-80{ }^{\circ} \mathrm{C}$.

Following jar-test experiments, the water samples were serially diluted (10-fold) in 1X PBS (sufficient for up to 4.5-log removal) and were promptly assayed using conventional in vitro cell culture methodology. Cells were grown in 24-well cell culture trays. Each sample dilution was used to inoculate four wells, using $0.1 \mathrm{~mL}$ of sample per well. The trays were incubated in a $5 \% \mathrm{CO}_{2}$ incubator at $37^{\circ} \mathrm{C}$ and were examined daily for any cytopathogenic effects (CPE) for up to 14 days. Typically, CPE manifested itself as cell enlargement, rounding, and the formation of grape-like clusters. ${ }^{24}$ The Karber TCID 50 method was used to quantify the viral concentration of each sample. The Karber $\mathrm{TCID}_{50}$ equation is a statistical approach used to estimate the concentration at which $50 \%$ of the inoculated wells are positive for infection, ${ }^{24}$ as follows

$$
\operatorname{TCID}_{50}=10^{-[(\alpha-6)(3-0,5)]}
$$

where $\Delta$ is the logarithm of the most diluted sample with $100 \%$ infectivity, $a$ is the logarithm of the dilution factor, and $S$ is the sum of the normalized positive infections including both the last $100 \%$ and the first $0 \%$ infectious dilutions.

\section{Chemical Parameter Analysis.}

The samples were analyzed for $\mathrm{pH}$, turbidity, $\mathrm{DOC}$, and $\mathrm{UV}_{254}$, all of which can affect the efficiency of coagulation. The $\mathrm{pH}$ was measured

Environmental Science \& Technology, Vol 41, No. 3 (2007): pg. 971-977. DOI. This article is @ American Chemical Society and permission has been granted for this version to appear in e-Publications@Marquette. American Chemical Society does not grant permission for this article to be further copied/distributed or hosted elsewhere without the express permission from American Chemical Society. 
using a Mettler (Columbus, $\mathrm{OH}$ ) pH meter. Turbidity was measured using a Hach (Loveland, CO) model 2100P turbidimeter. For DOC determination, samples were filtered using $1.2-\mu \mathrm{m}$ Whatman (Middlesex, U.K.) GF/C glass microfiber filters, acidified using $1 \mathrm{~N} \mathrm{HCl}$, and analyzed using a Shimadzu 5050A (Kyoto, Japan) Total Organic Carbon Analyzer. A Shimadzu Multispec 1501 spectrometer was used to measure $U_{254}$.

\section{Statistical Analysis.}

Statistical analyses were performed to determine whether the mean microbial removals resulting from different treatment conditions were statistically different at a significance level of $a=0.05$. SPSS (Chicago, IL) version 12.0 statistical software was used for the analyses. An analysis of variance (ANOVA) test was used to test the equality of means. The Levene statistic was computed to test the ANOVA assumption of equal variances. ${ }^{25}$ The Welch test of equality of means was used for data not satisfying the equal-variance assumption. ${ }^{26}$ Upon determination that the means were significantly different, post hoc tests were used to determine which means were different from one another. Tukey's honestly significant difference (HSD) test was used to test data with equal variances, ${ }^{27}$ and the Games-Howell test was used to analyze data that did not satisfy the equal-variances assumption. ${ }^{28}$

\section{Quality Assurance and Quality Control (QA/QC).}

The standard QA/QC procedures for laboratories performing microbial and chemical analyses on water samples were followed during this research. ${ }^{29,30}$ Additional details of the QA/QC plan are described in each subsection of the Materials and Methods.

\section{Results and Discussion}

\section{Coagulant Dose-Optimization Jar Tests.}

DOC Removal. In all three dose-optimization experiments, $25 \%$ or greater DOC removal was achieved using coagulant doses of 40 $\mathrm{mg} / \mathrm{L}$ or greater $\mathrm{FeCl}_{3}$ (Figures 1 and 2and Tables 2-4 in the and permission has been granted for this version to appear in e-Publications@Marquette. American Chemical Society does not grant permission for this article to be further copied/distributed or hosted elsewhere without the express permission from American Chemical Society. 
Supporting Information), which satisfies the USEPA guidelines for enhanced coagulation. ${ }^{3}$ The guidelines define which utilities are required to practice enhanced coagulation, as dictated by initial water quality. This particular water would be exempt from the requirement based on DOC content in the source water, ${ }^{3}$ which is an extremely important consideration for the full-scale treatment plant. However, because the objective was to evaluate virus removal resulting from enhanced coagulation, enhanced coagulation condi tions were employed throughout this study, and optimization recommendations based on DOC removal were made accordingly.

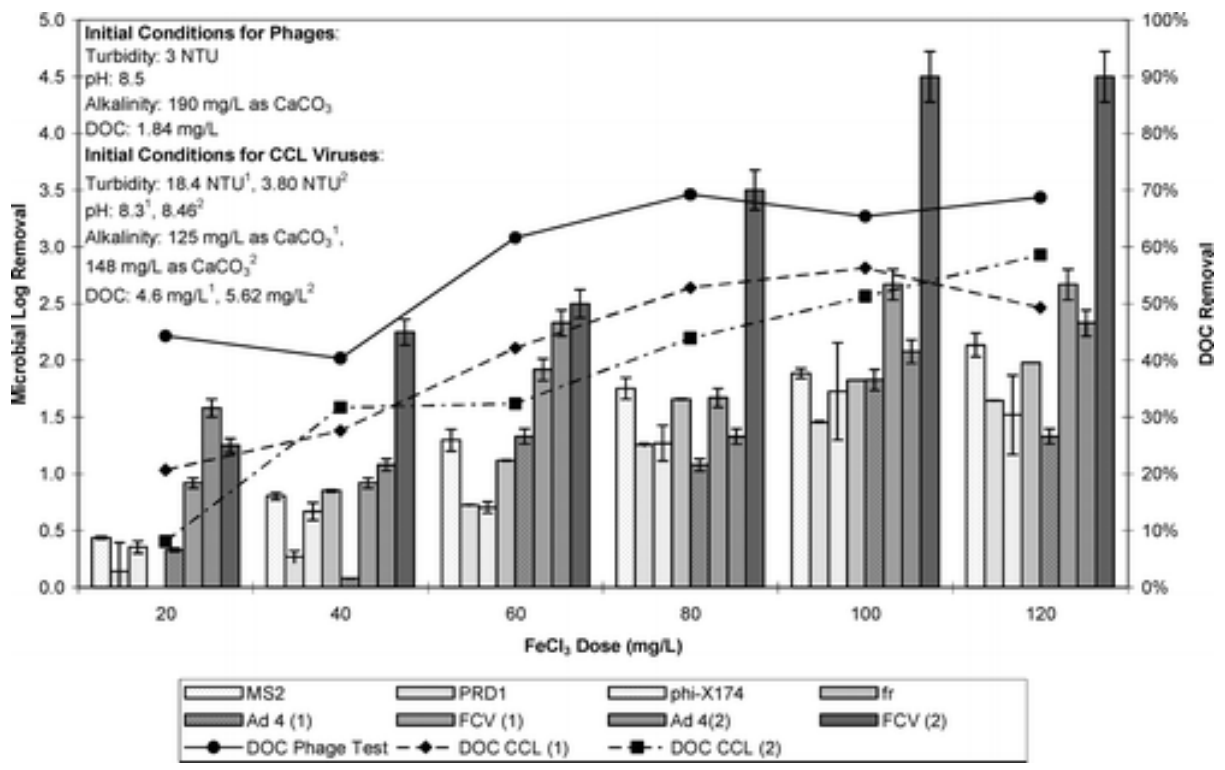

Figure 1 Removal of microbes and $\mathrm{DOC}$ as a function of $\mathrm{FeCl}_{3}$ dose in the three jar tests: phage test, first CCL virus removal experiment (1), and second CCL virus removal experiment (2). The error bars represent \pm 1 standard deviation for the bacteriophages and $\pm 5 \%$ for the $C C L$ viruses. The DAL analysis was inconclusive for $\mathrm{fr}$ at a dose of $20 \mathrm{mg} / \mathrm{L}$. Removals of FCV (1) and FCV (2) at coagulant doses of 100 and $120 \mathrm{mg} / \mathrm{L} \mathrm{FeCl}_{3}$ represent the maximum calculable removals based on the cell culture experiment. 
NOT THE PUBLISHED VERSION; this is the author's final, peer-reviewed manuscript. The published version may be accessed by following the link in the citation at the bottom of the page.

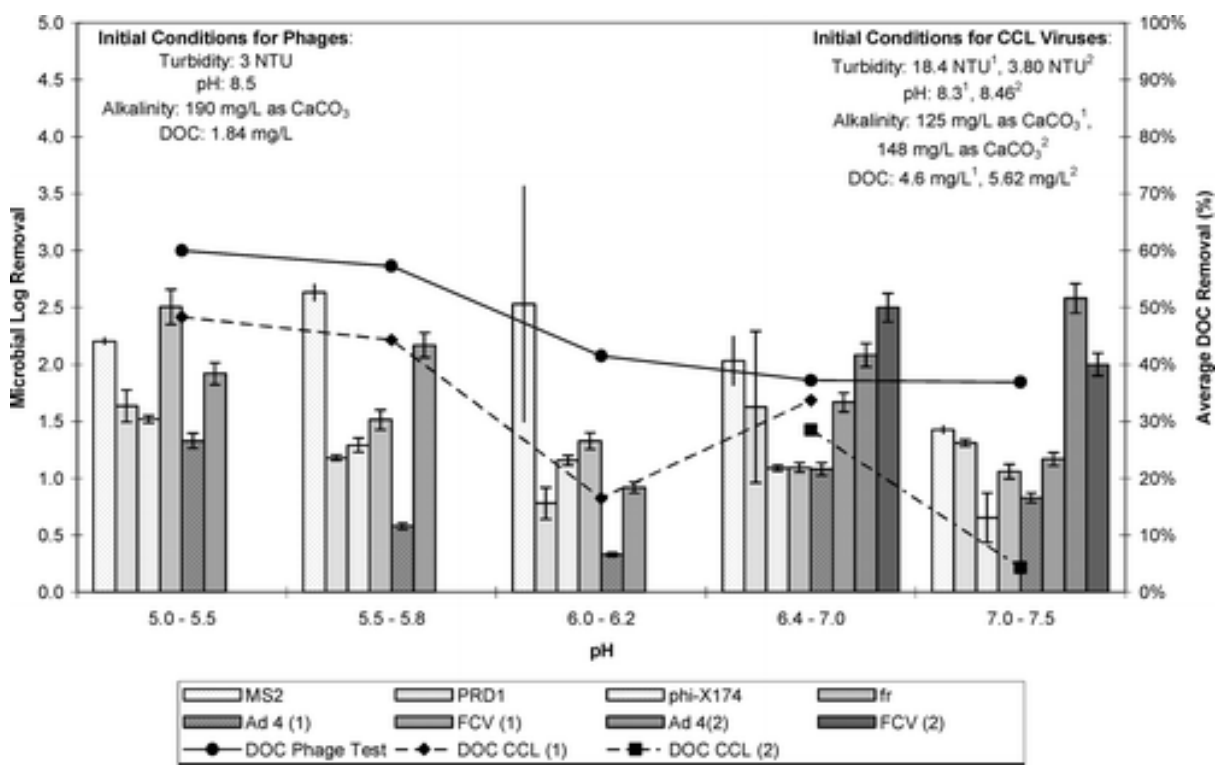

Figure 2 Removal of microbes and $\mathrm{DOC}$ as a function of $\mathrm{pH}$ adjustment in the three jar tests: phage test, first CCL virus removal experiment (1), and second CCL virus removal experiment (2). The error bars represent \pm 1 standard deviation for the bacteriophages and $\pm 5 \%$ for the $\mathrm{CCL}$ viruses. A pH range is provided because the final $\mathrm{pH}$ varied slightly between the jar tests. Because of difficulties adjusting the $\mathrm{pH}$ to target levels, no data are available for the second (2) CCL virus removal experiment for the $\mathrm{pH}$ range from 5 to 6 .

The USEPA has established the optimal coagulant dose for DOC removal as the point of diminishing return (PODR). ${ }^{3}$ The PODR is defined as the dose at which the change in DOC removal divided by the change in coagulant addition drops to (and subsequently remains below) $0.03 .^{3}$ Using the PODR criterion, the optimum ferric chloride dose for DOC removal was determined to be $40 \mathrm{mg} / \mathrm{L}$ based on the bacteriophage experiment, $80 \mathrm{mg} / \mathrm{L}$ based on the first CCL virus experiment, and $80 \mathrm{mg} / \mathrm{L}$ based on the second $\mathrm{CCL}$ virus experiment. The complete results of the chemical analyses for the doseoptimization experiments are provided in Tables 2-4 in the Supporting Information.

\section{Bacteriophage Removal. Bacteriophage removal generally} increased as coagulant dose increased (Figure 1). MS2 was generally removed to the greatest extent, followed by $\mathrm{fr}$, phi-X174, and PRD1. These results are comparable to those of previous studies in that male-specific bacteriophages such as MS2 and fr were removed to a greater extent than somatic bacteriophages such as PRD1 and phiX174 $(7,8,31)$. 
The quantification of virus removal during physical and chemical separation processes is well documented. ${ }^{32-34}$ It appears that the main mechanism for the physical removal of viruses is adsorption and charge neutralization followed by gravitational separation; however, the details of virus adsorption during coagulation and flocculation are not yet fully understood. Studies of transport through soil matrices have indicated that the adsorption of viruses is a complex process in which hydrophobicity, surface charge, and isoelectric point (pI) are influential factors. ${ }^{13,34}$ It appears that no individual factor can adequately explain the mech anism of virus adsorption. Isoelectric point has been suggested to be the dominant factor controlling virus adsorption during transport through sandy soils. ${ }^{13}$ Although the complete effects of the addition of coagulant, specifically on the surface charge of the virus, are not fully understood, the pI can help to explain adsorption during coagulation. The isoelectric points of the bacterioph ages are listed in Table 1 . The pI of $\mathrm{fr}$ is relatively high, meaning that its surface is positively charged in most naturally occurring $\mathrm{pH}$ ranges $(6-8)$. This enables $\mathrm{fr}$ to adsorb to the surface of negatively charged particles such as $\mathrm{Fe}(\mathrm{OH})_{4}^{-}$. In the same $\mathrm{pH}$ range, other phages such as MS2 and PRD1 are negatively charged, thereby allowing them to adsorb to positively charged species such as $\mathrm{Fe}(\mathrm{OH})_{2}{ }^{+}$. Theoretically, as the absolute value between $\mathrm{pH}$ and virus $\mathrm{pI}$ increases, the magnitude of the surface charge increases, thereby improving the efficacy of adsorption. This supports the observation that MS2 and fr were removed to a greater extent than phi-X174, but does not account for the relatively low removal of PRD1. Although the exact mechanisms cannot be identified as a result of this study, it is apparent that multiple factors contribute to the adsorption and resultant removal of viruses during treatment processes.

Statistical analyses were performed using the mean logarithms of the removals of the bacteriophages $(n=3)$ at different coagulant doses to determine the optimal dose required to produce a significant degree of virus removal (as described in Table 6 in the Supporting Information). For each of the four bacteriophages, there was a significant difference between the log removal values at different coagulant doses $(P \leq 0.01)$ (Table 5 in the Supporting Information). The results indicate that $80 \mathrm{mg} / \mathrm{L}$ is the optimal dose for MS2 removal, 
$80 \mathrm{mg} / \mathrm{L}$ for PRD1, $40 \mathrm{mg} / \mathrm{L}$ for phi-X174, and >120 mg/L for fr (Table 6 in the Supporting Information).

CCL Virus Removal. The log removal values calculated for the two CCL virus removal experiments appear to differ from one another, although this could not be verified statistically as the two experiments were not regarded as replicates because of differing initial water qualities. Overall, FCV was removed to a greater extent than Ad4 (Figure 1). There was an increase in removal of Ad4 and FCV at a dose of $60 \mathrm{mg} / \mathrm{L}$ and again at $100 \mathrm{mg} / \mathrm{L}$ for the first CCL virus experiment. For the second CCL virus experiment, there was an improvement in FCV removal at doses of 80 and $100 \mathrm{mg} / \mathrm{L}$, whereas the results for Ad4 did not clearly identify an optimal dose. This indicates that an optimal dose for virus removal might be 60,80 , or $100 \mathrm{mg} / \mathrm{L} \mathrm{FeCl}_{3}$, which is similar to the range for the bacteriophages.

FCV appeared to be removed to a greater extent than the four bacteriophages, thereby indicating that the bacterioph ages might be potential surrogates. Bacteriophages MS2 and fr would be more representative surrogates, whereas phi-X174 and PRD1 appear to be more conservative because they were removed to a lesser extent. Adenovirus was not consistently removed to a greater extent than the bacteriophages (particularly in the first CCL virus experiment); thus, it does not appear that the bacteriophages would be appropriate surrogates for Ad4.

In summary, the dose-optimization experiments sug gested a wide variation in optimal coagulant doses based on different criteria (i.e., from $40 \mathrm{mg} / \mathrm{L}$ based on DOC removal to greater than $120 \mathrm{mg} / \mathrm{L}$ based on the removal of the bacteriophage $\mathrm{fr}$ ). In light of this result, it might be beneficial to consider microbial removal in addition to DOC removal when optimizing coagulant doses. However, regulations regarding the performance of enhanced coagulation currently refer only to DOC removal. Therefore, a dose of $40 \mathrm{mg} / \mathrm{L} \mathrm{FeCl}_{3}$ was identified as the optimal dose for enhanced coagulation because it was the lowest dose shown to produce a significant reduction in DOC content. Accordingly, a dose of $40 \mathrm{mg} / \mathrm{L} \mathrm{FeCl}_{3}$ was used to conduct the $\mathrm{pH}$-optimization jar tests and the pilot-plant study. 
NOT THE PUBLISHED VERSION; this is the author's final, peer-reviewed manuscript. The published version may be accessed by following the link in the citation at the bottom of the page.

\section{pH-Optimization Jar Tests.}

DOC Removal. The $\mathrm{pH}$-optimization jar tests (Figure 2 and Tables 7-9 in the Supporting Information) satisfied the USEPA enhanced coagulation guidelines by achieving at least $25 \%$ DOC removal. ${ }^{3}$ The optimal $\mathrm{pH}$ cannot be determined using the PODR calculation, as was done to optimize dose, because the PODR is calculated using the change in DOC removal relative to coagulant dose increments. However, substantial improve ments in DOC removals were observed between $\mathrm{pH} 6.01$ and 5.55 and between $\mathrm{pH} 6.16$ and 5.73 based on the bacteriophage and the first CCL virus removal experiments, respectively. Judging from these experiments, it appears that the optimal $\mathrm{pH}$ range with respect to DOC removal is less than 6.0. The complete results of the chemical analyses for the $\mathrm{pH}$ optimization experiments are provided in Tables 7-9 in the Supporting Information.

Bacteriophage Removal. Bacteriophage MS2 was generally removed to the greatest extent, followed by $\mathrm{fr}$, phi-X174, and PRD1 (Figure 2). There was a statistically significant difference between the mean log removal values at different $\mathrm{pH}$ values for each of the bacteriophages tested $(P \leq 0.01$ ) (Table 10 in the Supporting Information). The post hoc tests indicate that the optimal $\mathrm{pH}$ is less than 6.0 for PRD1 removal and less than 5.55 for phi-X174 and $\mathrm{fr}$ removal, whereas an optimal $\mathrm{pH}$ for removal of MS2 could not be identified (Table 11 in the Supporting Information).

CCL Virus Removal. Differences in initial water qualities between the two tests prevented a statistical comparison of the means of the log removal values of the two $\mathrm{CCL}$ viruses at each $\mathrm{pH}$ value. However, it was apparent that FCV was removed to a greater extent than Ad4. Furthermore, there was an increase in removal of viruses between $\mathrm{pH}$ 6.0 and 5.5 for the first CCL virus experiment (Figure 2), thereby indicating that an optimal $\mathrm{pH}$ for virus removal might be less than 6.0. Practical limitations effectively impart a lower $\mathrm{pH}$ boundary of $5 ;{ }^{2}$ thus, the recommended $\mathrm{pH}$ range was 5-6.

Data from the first CCL virus experiment indicate that the four bacteriophages are not appropriate CCL virus surrogates given that, in

Environmental Science \& Technology, Vol 41, No. 3 (2007): pg. 971-977. DOI. This article is @ American Chemical Society and permission has been granted for this version to appear in e-Publications@Marquette. American Chemical Society does not grant permission for this article to be further copied/distributed or hosted elsewhere without the express permission from American Chemical Society. 
many cases, the bacteriophages were removed more efficiently. However, the results of the second CCL virus experiment show that the CCL viruses were removed to a greater extent than the bacteriophages. Thus, the bacteriophages were not eliminated as potential CCL surrogates. It would be beneficial to conduct future studies to confirm the suitability of the bacteriophages as potential $\mathrm{CCL}$ virus surrogates.

In summary, bench-scale testing demonstrated that the optimal conditions for enhanced coagulation were $40 \mathrm{mg} / \mathrm{L} \mathrm{FeCl}_{3}$ and a $\mathrm{pH}$ between 5 and 6 . These conditions resulted in maximum removals of $2.58 \mathrm{log}$ units of adenovirus type 4, $2.50 \mathrm{log}$ units of feline calicivirus, $2.32 \log$ units of MS2, $1.75 \log$ units of PRD1, $1.52 \log$ units of phi$\mathrm{X} 174,2.49 \log$ units of $\mathrm{fr}$, and $56 \%$ of DOC.

\section{Pilot-Plant Tests.}

The pilot plant was operated at a coagulant dose of $40 \mathrm{mg} / \mathrm{L}$ $\mathrm{FeCl}_{3}$ and a target $\mathrm{pH}$ between 5 and 6 based on the optimization experiments. The pilot-scale study satisfied the USEPA's DOC removal guidelines $^{3}$ (Table 12 in the Supporting Information). The complete results of the chemical analyses for the pilot-plant experi ments are provided in Table 12 in the Supporting Information.

The log removal values of the bacteriophages are listed in Table 2. Following filtration, fr was removed to the greatest extent at the high flow rate of $0.5 \mathrm{gpm}\left(10 \mathrm{gpm} / \mathrm{ft}^{2}\right)$, followed by PRD1, MS2, and phi-X174. At the low flow rate of $0.25 \mathrm{gpm}\left(5 \mathrm{gpm} / \mathrm{ft}^{2}\right)$, PRD1 was removed to the greatest extent, followed by MS2, fr, and phi-X174. The pilot-plant removals represented physical removal by coagulation, sedimentation, and filtration, whereas the jar-test data did not include filtration. Jar-test results compare to the settled water (prior to filtration) for the pilot-plant experiments. For the settled water, fr was removed to the greatest extent, followed by MS2, PRD1, and phi$\mathrm{X} 174$. The trend in virus removals (MS2 and fr > phi-X174 and PRD1) was consistent between bench- and pilot-scale testing; however, pilotplant removals exceeded bench-scale removals, which is consistent with previous reports. ${ }^{34}$ 
NOT THE PUBLISHED VERSION; this is the author's final, peer-reviewed manuscript. The published version may be accessed by following the link in the citation at the bottom of the page.

Table 2. Log Removal Values of Bacteriophages at Different Stages of the Pilot Plant

\begin{tabular}{|c|c|c|c|c|}
\hline \multirow[b]{2}{*}{$\begin{array}{l}\text { bacteriophag } \\
\text { e }\end{array}$} & \multicolumn{2}{|c|}{$\begin{array}{l}\text { low flow rate: }{ }^{a} 0.25 \mathrm{gpm}\left(5 \mathrm{gpm} / \mathrm{ft}^{2}\right. \\
\end{array}$} & \multicolumn{2}{|c|}{ high flow rate: ${ }^{b} 0.5 \mathrm{gpm}\left(10 \mathrm{gpm} / \mathrm{ft}^{2}\right.$} \\
\hline & settled water & filtered water & settled water & filtered water \\
\hline MS2 & 3.94 & 4.60 & 4.28 & 6.87 \\
\hline PRD1 & 3.73 & 6.67 & 4.03 & 7.14 \\
\hline phi-X174 & 3.28 & 3.94 & 3.53 & 4.47 \\
\hline $\mathrm{fr}$ & 3.97 & 4.54 & 4.34 & 7.87 \\
\hline
\end{tabular}

There was a statistically significant difference between the removals of the bacteriophages at the high and low flow rates, except for the overall removal of PRD1 and the removal of fr by sedimentation $(P \leq 0.01)$ (Table 13 in the Supporting Information). The low flow rate should provide a better degree of removal; however, the data indicate that greater bacteriophage removals were achieved at the high flow rate. One possible explanation is the difference in initial water quality, which can affect statistical analyses; therefore, the relative efficacy of removal for the different water flow rates was not considered conclusive.

In summary, the results of the treatment optimization jar tests indicated that an optimal coagulant dose for DOC removal was 40 $\mathrm{mg} / \mathrm{L} \mathrm{FeCl}_{3}$ with $\mathrm{pH}$ adjustment to between 5 and 6 . Considering sedimentation only, MS2 and fr were removed to a greater extent than PRD1 and phi-X174; however, PRD1 exhibited a comparatively high degree of removal during filtration. Bacteriophages MS2, PRD1, phi$\mathrm{X} 174$, and fr appear to be suitable potential surrogates for FCV, with MS2 and fr being more representative. Adenovirus type 4 seemed to be more resistant to physical and chemical treatment processes than FCV and the four bacteriophages tested, thereby indicating that the bacteriophages might not be appropriate potential surrogates for Ad4.

\section{Acknowledgment}

This work was supported by the Office of Water, United States Environmental Protection Agency under Contract 4C-W010-NAEX. The opinions expressed in

Environmental Science \& Technology, Vol 41, No. 3 (2007): pg. 971-977. DOI. This article is @ American Chemical Society and permission has been granted for this version to appear in e-Publications@Marquette. American Chemical Society does not grant permission for this article to be further copied/distributed or hosted elsewhere without the express permission from American Chemical Society. 
NOT THE PUBLISHED VERSION; this is the author's final, peer-reviewed manuscript. The published version may be accessed by following the link in the citation at the bottom of the page.

this article are those of the authors and not necessarily those of the EPA. B.K.M. is the recipient of a Department of Homeland Security Fellowship. The mention of product names does not constitute endorse ment of the company.

\section{Supporting Information Available}

Data sets for the chemical analyses and summary tables of the statistical analyses. This material is available free of charge via the Internet at http://pubs.acs.org.

\section{References}

${ }^{1}$ Kastl, G.; Sathasivan, A.; Fisher, I.; van Leewen, J. Modeling DOC removal by enhanced coagulation. J. Am. Water Works Assoc. 2004, 96, 79-89.

${ }^{2}$ Childress, A. E.; Vrijenhoek, E. M.; Elimelech, M.; Tanaka, T. S.; Beuhler, M. D. Particulate and THM precursor removal with ferric chloride. J. Environ. Eng. 1999, 125, 1054-1061.

${ }^{3}$ Enhanced Coagulation and Enhanced Precipitative Softening Guidance Manual; U.S. Environmental Protection Agency: Cincinnati, OH, 1999.

${ }^{4}$ Amirtharajah, A.; Dennett, K. E.; Studstill, A. Ferric chloride coagulation for removal of dissolved organic matter and trihalomethane precursors. Water Sci. Technol. 1993, 27, 113-121.

${ }^{5}$ Volk, C.; Bell, K.; Ibrahim, E.; Verges, D.; Amy, G.; Lechevallier, M. Impact of enhanced and optimized coagulation on removal of organic matter and its biodegradable fraction in drinking water. Water Res. 1999, 34, 3247-3257.

${ }^{6}$ Edzwald, J. K.; Tobiason, J. E. Enhanced coagulation: US requirements and a broader view. Water Sci. Technol. 1999, 40, 63 -70.

7Jofre, J.; Olle, E.; Ribas, F.; Vidal, A.; Lucena, F. Potential usefulness of bacteriophages that infect Bacteroides frageilis as model organisms for monitoring virus removal in drinking water treatment plants. Appl.

Environ. Microbiol. 1995, 61, 3227-3231.

${ }^{8}$ Gerba, C. P.; Riley, K. R.; Nwachuku, N.; Ryu, H.; Abbaszadegan, M. Removal of Enchephalitozoon intestinalis, calicivirus, and coliphages by conventional drinking water treatment. J. Environ. Sci. 2003, A38, $1259-1268$

${ }^{9}$ Xagoraraki, I.; Harrington, G. W.; Assavasilavasukul, P.; Standridge, J. H. Removal of emerging waterborne pathogens and pathogen indicators by pilot-scale conventional treatment. J. Am. Water Works Assoc. 2004, 96, 102-113.

Environmental Science \& Technology, Vol 41, No. 3 (2007): pg. 971-977. DOI. This article is @ American Chemical Society and permission has been granted for this version to appear in e-Publications@Marquette. American Chemical Society does not grant permission for this article to be further copied/distributed or hosted elsewhere without the express permission from American Chemical Society. 
NOT THE PUBLISHED VERSION; this is the author's final, peer-reviewed manuscript. The published version may be accessed by following the link in the citation at the bottom of the page.

${ }^{10}$ Drinking Water Contaminant Candidate List 2; U.S. Environmental Protection Agency: Washington, DC, Nov 2006 (updated); available at http://www.epa.gov/ogwdw/ccl/ccl2.html.

${ }^{11}$ Doultree, J. C.; Druce, J. D.; Birch, C. J.; Bowden, D. S.; Marshall, J. A. Inactivation of feline calicivirus, a Norwalk virus surrogate. J. Hosp. Infect. 1999, 41, 51-57.

${ }^{12}$ Slomka, M. J.; Appleton, H. Feline calicivirus as a model system for heat inactivation studies of small round structured viruses in shellfish. Epidemiol. Infect. 1998, 121, 401-407.

${ }^{13}$ Dowd, S. E.; Pillai, S. D.; Wang, S.; Corapcioglu, M. Y. Delineating the specific influence of virus isoelectric point and size on virus adsorption and transport through sandy soils. Appl. Environ. Microbiol. 1998, 64, $405-410$

${ }^{14}$ Schijven, J. F.; Hassanizadeh, S. M.; de Bruin, H. A. M. Column experiments to study nonlinear removal of bacteriophages by passage through saturated dune sand. J. Contam. Hydrol. 2002, 58, 243-259.

${ }^{15}$ Sokolova, A.; Malfois, M.; Caldentey, J.; Svergun, D. I.; Koch, M. H. J.; Bamford, D. H.; Tuma, R. Solution structure of bacteriophage PRD1 vertex complex. J. Biol. Chem. 2001, 276, 46187-46189.

${ }^{16}$ Nader, W. Validation of a UF system for the removal of viruses and scrapie agent. Genet. Eng. News 1994, 14, 19-22.

${ }^{17}$ Crittenden, J. C.; Trussell, R. R.; Hand, D. W.; Howe, K. J.; Tchobanoglous, G., Eds. Water Treatment: Principals and Design, 2nd ed.; John Wiley: New York, 2005.

${ }^{18}$ Fong, T. T.; Lipp, E. K. Enteric viruses of humans and animals in aquatic environments: Health risks, detection, and potential water quality assessment tools. Microbiol. Mol. Biol. Rev. 2005, 69, 357-371.

${ }^{19}$ Atmar, R. L.; Estes, M. K. Diagnosis of noncultivatable gastroenteritis viruses, the human caliciviruses. Clin. Microbiol. Rev. 2001, 14, $15-37$.

${ }^{20}$ Budd, G. C.; Hess, A. F.; Shorney-Darby, H.; Neemann, J. J.; Spencer, C. M.; Bellamy, J. D.; Hargette, P. H. Coagulation applications for new treatment goals. J. Am. Water Works Assoc. 2004, 96, 102-113.

${ }^{21}$ Fisher, I.; Kastl, G.; Sathasivan, A.; Chen, P.; van Leeuwen, J.; Daly, R.; Holmes, M. Tuning the enhanced coagulation process to obtain the best chlorine and THM profiles in the distribution system. Water Sci. Technol., Water Supply 2004, 4, 235-243.

${ }^{22}$ Adams, M. H. In Bacteriophages; Interscience Publishers: New York, 1959.

${ }^{23}$ Thurston-Enriquez, J. A.; Haas, C. N.; Jacangelo, J.; Riley, K.; Gerba, C. P. Inactivation of feline calicivirus and adenovirus type 40 by UV radiation. Appl. Environ. Microbiol. 2003, 69, 577-582.

${ }^{24}$ Payment, P.; Trudel, M. Methods and Techniques in Virology; Marcel Dekker: New York, 1993.

Environmental Science \& Technology, Vol 41, No. 3 (2007): pg. 971-977. DOI. This article is @ American Chemical Society and permission has been granted for this version to appear in e-Publications@Marquette. American Chemical Society does not grant permission for this article to be further copied/distributed or hosted elsewhere without the express permission from American Chemical Society. 
NOT THE PUBLISHED VERSION; this is the author's final, peer-reviewed manuscript. The published version may be accessed by following the link in the citation at the bottom of the page.

${ }^{25}$ Levene, H. Robust tests for equality of variances. In Contributions to Probability and Statistics; Olkin, I., Ed.; Stanford University Press: Palo Alto, CA, 1960, 278-292.

${ }^{26}$ Welch, B. L. On the comparison of several mean values: an alternate approach. Biometrika 1951, 38, 330-336.

${ }^{27}$ Kirk, R. Experimental Design: Procedures for the Behavioral Sciences; Brooks/Cole: Belmont, MA, 1968.

${ }^{28}$ Games, P. A.; Howell, J. H. Pairwise multiple comparison procedures with unequal $N$ 's and/or variances: A Monte Carlo study. J. Educ. Stat. 1976, 1, 113-125.

${ }^{29}$ ICR Microbiology Laboratory Manual; Report EPA-600-R-95-178; Office of Research and Development, U.S. Environmental Protection Agency: Washington, DC, 1996.

${ }^{30}$ Eaton, A.; Clesceri, L.; Greenberg, A. Standard Methods for the Examination of Water and Wastewater, 21st ed; APHA, AWWA, WEF: Washington, DC, 2005.

${ }^{31}$ Yahya, M. T.; Galsomies, L.; Gerba, C. P.; Bales, R. C. Survival of bacteriophages MS2 and PRD1 in groundwater. Water Sci. Technol. 1993, 27, 409-412.

${ }^{32}$ Robeck, G. G.; Clark, N. E.; Dostal, K. A. Effectiveness of water treatment processes in virus removal. J. Am. Water Works Assoc. 1962, 54, $1275-1292$.

${ }^{33}$ Chauduri, M.; Engelbrecht, R. S. Removal of viruses from water by chemical coagulation and flocculation. J. Am. Water Works Assoc. 1970, 62, 563-567.

${ }^{34}$ Rao, V. C.; Symons, J. M.; Ling, A.; Wang, P.; Metcalf, T. G.; Hoff, J. C.; Melnick, J. L. Removal of Hepatitis A viruses and rotavirus by drinking water treatment. J. Am. Water Works Assoc. 1988, 80, 59-67.

Environmental Science \& Technology, Vol 41, No. 3 (2007): pg. 971-977. DOI. This article is @ American Chemical Society and permission has been granted for this version to appear in e-Publications@Marquette. American Chemical Society does not grant permission for this article to be further copied/distributed or hosted elsewhere without the express permission from American Chemical Society. 